\title{
The place of qualitative research in Evidence-Based Practice
}

Cristina Lavareda Baixinho'
ORCID: 0000-0001-7417-1732

Maria Helena Carvalho Valente Presado' ORCID: 0000-0002-6852-7875

Ellen Synthia Fernandes de Oliveira" ORCID: 0000-0002-0683-2620

'Escola Superior de Enfermagem de Lisboa. Lisboa, Portugal. "Universidade Federal de Goiás. Goiânia, Goiás, Brazil.

How to cite this article: Baixinho CL, Presado MHCV, Oliveira ESF. The place of qualitative research in Evidence-Based Practice. Rev Bras Enferm. 2020;73(5):e2020n5. doi: http://dx.doi.org/10.1590/0034-7167-2020730501
In the discourse of health professionals and even policy makers, allusion to the concept of Evidence-Based Practice (EBP) often emerges. Such allusion refers to EBP countless benefits, with which we agree, but the question that guides us in this editorial is whether we really have a true EBP and what is the place of qualitative research in this practice.

The evolution of health sciences and related-technologies has allowed an exponential increase in studies, however many of the research results end up having no direct impact on provision of care and definition of effective health policies. Delay in inserting evidence in clinical practice contexts $^{(1-2)}$ due to barriers that hinder the transfer of knowledge do not always allow decision making by health and management professionals, based on the most relevant research results ${ }^{(1)}$.

The etiology of this difficulty is diverse and touches on aspects ranging from the relevance of study design to praxis to difficulties in dissemination, including the low research culture of some institutions or the low literacy of health care clients ${ }^{(1)}$. It the clinic, professionals and researchers predominantly favor linear and unidirectional models to passively pass scientific information on to users and consumers ${ }^{(1-2)}$, with quantitative models prevailing ${ }^{(1)}$.

A quick reflection on EBP allows us to observe that in the different classifications of levels of evidence, randomized studies and systematic literature reviews with meta-analysis top the ranking ${ }^{(1)}$. Most of these studies are essentially related to technical interventions/procedures. Such procedures are referred to as best practices, but in reality they do not exhaust all clinical activity ${ }^{(1,3-4)}$, and do not allow citizen-centered care.

With the increase in qualitative research produced, there is a lack (from production, recommendations and transfer of evidence) of products, strategies and mechanisms that facilitate appropriation in contexts where complex decisions are made about the population's health-disease processes. Understanding singular realities is hardly viewed from a single prism, thus the reflection on the place and space of qualitative research arises in nursing ${ }^{(3)}$ and in health clinic.

We share the opinion of the authors who advocate that qualitative research is an inter and transdisciplinary field that crosses the humanities, social sciences, and natural sciences. The authors are convinced that the dialogue between theory and praxis, science-methods and techniques, and multidimensional human development requires different disciplinary views ${ }^{(3)}$. This makes it possible for the qualitative transformation of research to translate into better knowledge of transitions and adaptation processes in the face of health/disease, promoting quality of care, literacy and co-responsibility in health management ${ }^{(4)}$.

This 'qualitative challenge' for EBP certainly brings a fruitful discussion for researchers and advocates of levels of evidence from randomized studies or meta-analysis ${ }^{(1)}$. However, the development of qualitative research 
capable of placing this nature of research at a level capable of converging parallel to quantitative research, still hegemonic, in the health sector, brings potential not only for greater access to financing and an increase in publication ${ }^{(3)}$, but essentially for the impact on the population's health and quality of life.
Immersion in the process of knowledge and reflection motivates us to gather articles from the Ibero-American Congress on Qualitative Research (CIAIQ). CIAIQ was held in Lisbon-Portugal in 2019, contributing to the scientific and public debate on the place of research in EBP.

\section{REFERENCES}

1. Baixinho CL, Ferreira Ó, Marques FM, Presado MH, Cardoso M. Transição segura: um projeto da transferência do conhecimento para a prática clínica. In Costa AP, Sánches-Gómez MC, Cilleros MVM. (Eds). A prática na Investigação Qualitativa: exemplos de estudos (vol.1). Oliveira de Azeméis: Ludomédia; 2017, pp. 57-80.

2. Oelke ND, Lima MADS, Acosta AM. Knowledge translation: translating research into policy and practice. Rev Gaúcha Enferm. 2015;36(3):1137. doi: 10.1590/1983-1447.2015.03.55036

3. Oliveira ESF, Baixinho CL, Presado MHCV. Pesquisa qualitativa em saúde: uma abordagem reflexiva. Rev Bras Enferm. 2019;72(4):830-31. doi: 10.1590/0034-7167.2019-720401

4. Baixinho CL, Presado MH, Ribeiro J. Qualitative research and the transformation of public health. Cien Saude Colet. 2019;24(5):1583-3. doi: 10.1590/1413-81232018245.05962019 